\title{
Effect of Water Resources in the Queretaro River: Climate Analysis and Other Changes
}

\author{
E. González-Sosa, N.M. Ramos-Salinas, C.A. Mastachi-Loza and R. Becerril-Piña
}

Additional information is available at the end of the chapter

http://dx.doi.org/10.5772/55259

\section{Introduction}

Due to the imminent change of the continental surface and ocean temperature caused by the increase of greenhouse gases it is estimated that in the near future there may be a temperature increase of $3-4^{\circ} \mathrm{C}$. The average temperature increase could have repercussions in vast regions of the planet affecting both socio-economic and living conditions, infrastructure, development and ecosystems. Some scientists already predicted changes in the water cycle since the $70^{\prime} \mathrm{s}$, including an increase in temperature of 1.2 to $2.0^{\circ} \mathrm{C}$ [1]. The work conducted by the IPCC [2], reports alarming results; however, there is uncertainty about whether the effects are part of the climate variables or product of the effects of global climate changes also accentuated in certain regions of the world. In semi-arid regions as well as in other regions, the hydrological cycle is disturbing the regime even if the temperature changes were minor. An increase in the annual measured temperature of $1-2^{\circ} \mathrm{C}$ could reduce surface runoff between $40-70 \%$ and a $10 \%$ of the precipitation [3-4]. The consequences of such changes should also be considered as key and the link to other problems such as increased and drought severity, heat waves, floods, the water quality and the subsidence in urban centers, changes in land use and the availability of water in peri-urban watersheds. Furthermore, to investigate the changes of peri-urban watersheds and subsidence in large urban centers is of great relevance to the so-called emerging countries. The urbanization process transforms the land into different uses, and the spread urbanization, in many cases, cause forest and agricultural lands to disappear. Urbanization also affects the natural behavior of hydrological processes. Scientists recognize, however, that such impact is greater, for example, the global expansion of croplands since 1850 has transformed some 6 million $\mathrm{km}^{2}$ of wood forestlands and 4.7 million $\mathrm{km}^{2}$ of savannas/grasslands/steppes. Within these categories, 1.5 and 0.6 million $\mathrm{km}^{2}$ of croplands have already been abandoned [5]. By means of identifying the changes, land use can be the answer to identifying the main components of the hydrological processes that have been altered by human activities [6]. 
Throughout history, the management of water resources has played an important role in the development and civilization settlements. Within the last years, urban and peri-urban areas in Mexico have grown exponentially. Widespread urbanization generates land heterogeneity and fragmentation, diminishing natural resources and water supply. In fact, the settlements around of great cities produce changes in peri-urban catchments; therefore, the comprehension of their evolution is crucial and necessary for successful water resources management and territorial land use planning of high urbanization regions. The new settlements and land use changes are the articulation elements with the evolution of water resources [7]. The main effect produced by concentration in urban areas may be the decreasing in infiltration and increasing in surface runoff [8]. Fitzharris [9] found that the changes of land uses can alter the evapotranspiration, and hence runoff. The increase of runoff is produced by an increase of urbanization. These may be the study elements in order to solve water security concerns and water scarcity. Forefront, the increasing demands and decreasing supplies are the evaluation of disturbed level of the catchments to long term scenarios that are likely to be faced in the future [10]. In Brazil, it has been shown that forested areas have ten times the infiltration capacity of pastures deforestation, thus leading to a decrease in infiltration and increase in runoff. In Tanzania, the annual runoff from cultivated catchments is $30 \%-60 \%$ higher than that from similar catchments with original evergreen forest coverage [11]. The subsidence is another collateral problem in the world as well as in other large cities in Mexico caused by aquifers overexploitation. This vision seems consistent from the geological point of view; however, the subsidence problem has a greater importance in large urbanized areas due to its interaction with the environment and the collateral effects of climate change which generate great concentrated runoff pollutant loads and heavy metals, from cleaning products of streets and avenues, both negative as well as health matters. That is, the fractures caused by subsidies are common aquifer contamination ways, such are preferential flow paths to increase a point-source contamination in very short time, even hours, depending on the network connectivity among aquifer free surface. In other words, it is important to point out that recharge wells are part of efforts to mitigate soil cracks formation caused by subsidence; nevertheless, such become adverse because they also are sources of aquifers contamination by injecting contaminants throughout the internal flows. Those are generated through connections between soil cracks and because the deep recharge takes place in very short-terms compared to natural recharge times. In some cases, recharges take over hundreds of years, depending on the depth of the unsaturated zone and hydrodynamic properties of the soil. Mainly, it is very important if precipitation patterns are modifying by the effects of climate change.

\section{Water resources in Queretaro river basin}

Since the settlement of Queretaro City (Figure 1) in 1532 by the Otomi Kho-nin, also known as Fernando de Tapia, the population increase had a lien agricultural and industrial development. In 1743, the population was 5,849 habitants and after remained constant over 30,000 habitants during 1910 through 1940. Progress grew rapidly after the end of the Revolution. In 1950 the population reached 50,000 \& 130,000; by 1970: 641,386 in 1980, and 
by 2010 the city had overflowed other counties surpassing one million in habitants. During the same period, the territorial expansion produced an increase in the population density and modified substantially the land uses. The availability of water resources has also changed. Currently, $83 \%$ of the population is urban and $95 \%$ is regarded as rural-periurban. Figure 2 shows a trend of population, the spread urban surface and water supply evolution. Visibly, the trend is exponential from 1950, a similar condition for urban surface and water supply. The water supply flow in the beginning of the colonial period and the industrial development of Queretaro in 1700 was of $30 \mathrm{l} \mathrm{s}^{-1}$, from pumping springs located $100 \mathrm{~km}$ North of the city, and increased to $2360 \mathrm{l} \mathrm{s}^{-1}$ which was transferring from $200 \mathrm{~km}$ of neighbor basin, such representing a 147.5 times increase (Figure 2). The most important hydraulic infrastructure of water supply was carried out between 1726 and 1735, the $1280 \mathrm{~m}$ long aqueduct. The population estimated at the time was about 46472 habitants.

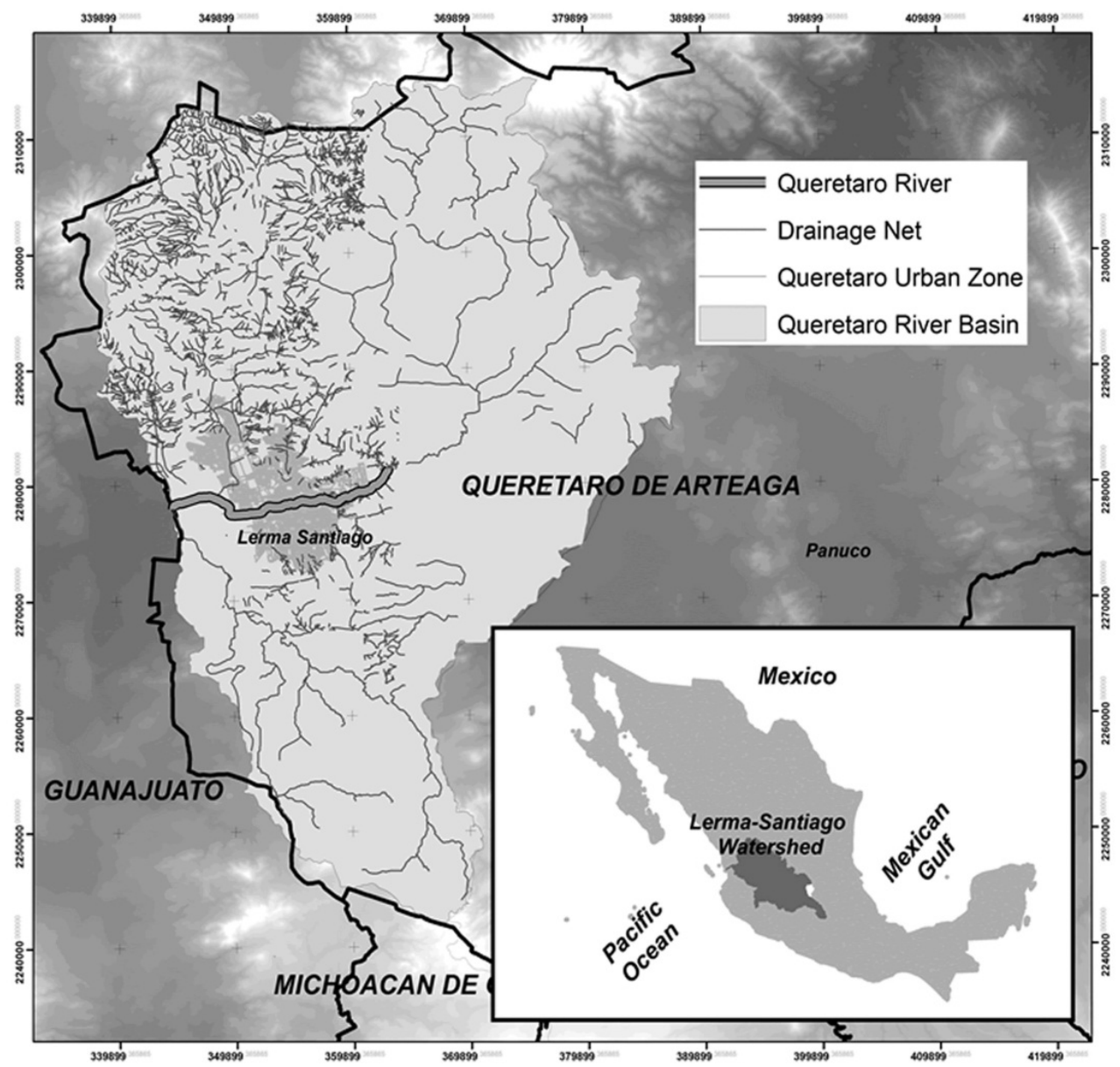

Figure 1. Location of Queretaro River Basin. 

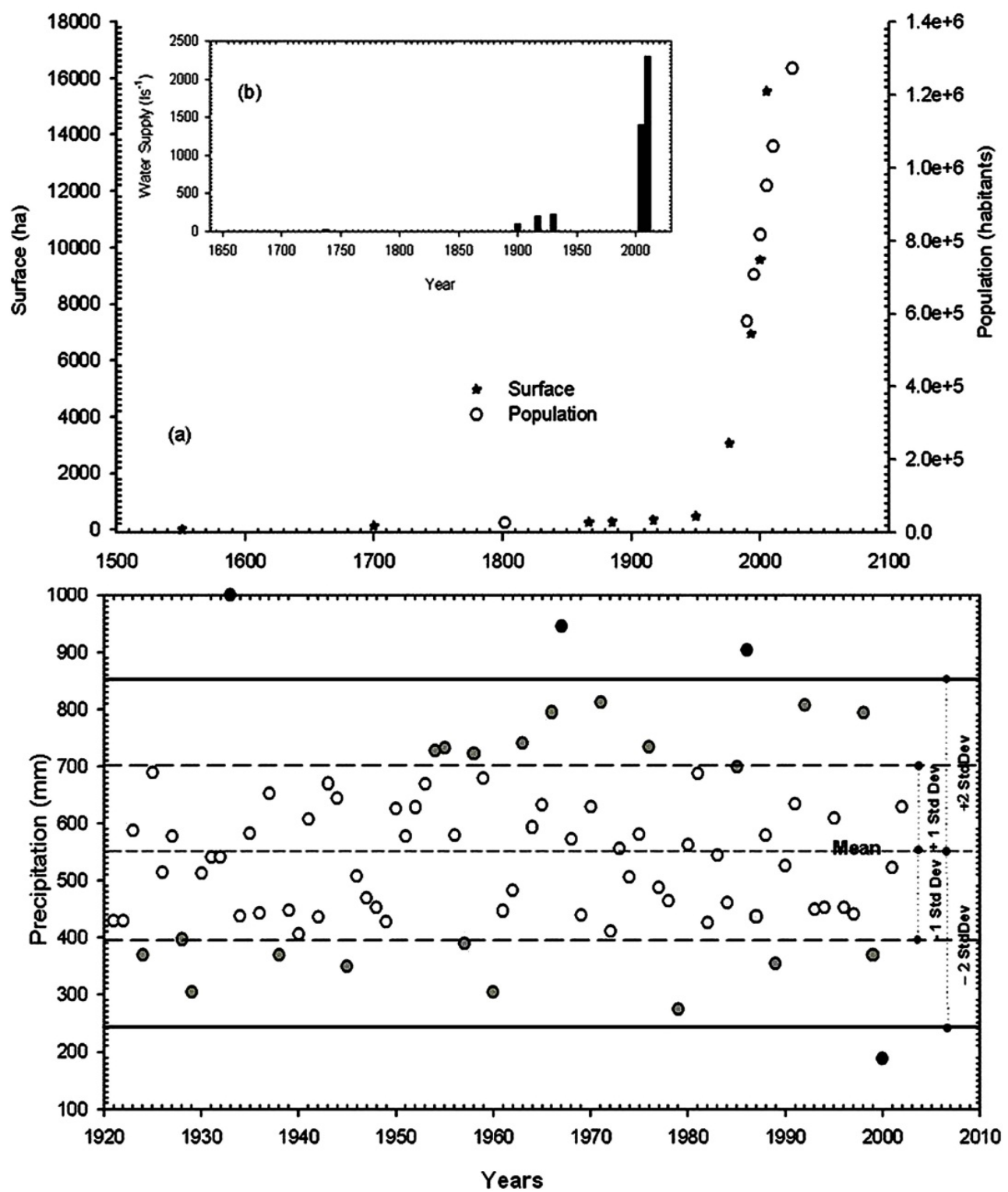

Figure 2. Population, urban surface and water supply evolution (above). Average annual precipitation in the "Observatorio Station", 1921-2007 (low).

Also, for this period there are existing reports that the water quality of the Queretaro River was polluted and people became ill after drinking such water as indicated by Von Humboldt in 1803 during his visit to Queretaro [12]. Official reports indicate that the water comes from the extraction of Queretaro's aquifers of Buena vista, Amazcala-Chichimequillas 
and Huimilpan located under the basin all being overexploited, as shown on Table 1 . Agriculture generally consumes 54\%, except in the Queretaro aquifer where most extractions are for urban public consumption. The water demand within the basin is estimated at 106 million $\mathrm{m}^{-3}$ Table 1 shows the five aquifers located in the Queretaro River's Basin where a deficit is observed due to high pumping for the supply of agriculture and urban water consumption. The Queretaro Water Commission (CEAQ) reported an annual average water reduction of $3 \mathrm{~m} \mathrm{y}^{-1}$ and in some sites twice as much; in the 40's the water table was at the surface. Furthermore, it was reported that for each $103 \mathrm{~m}^{3}$ pumping, only $70 \%$ is recovered through deep recharge.

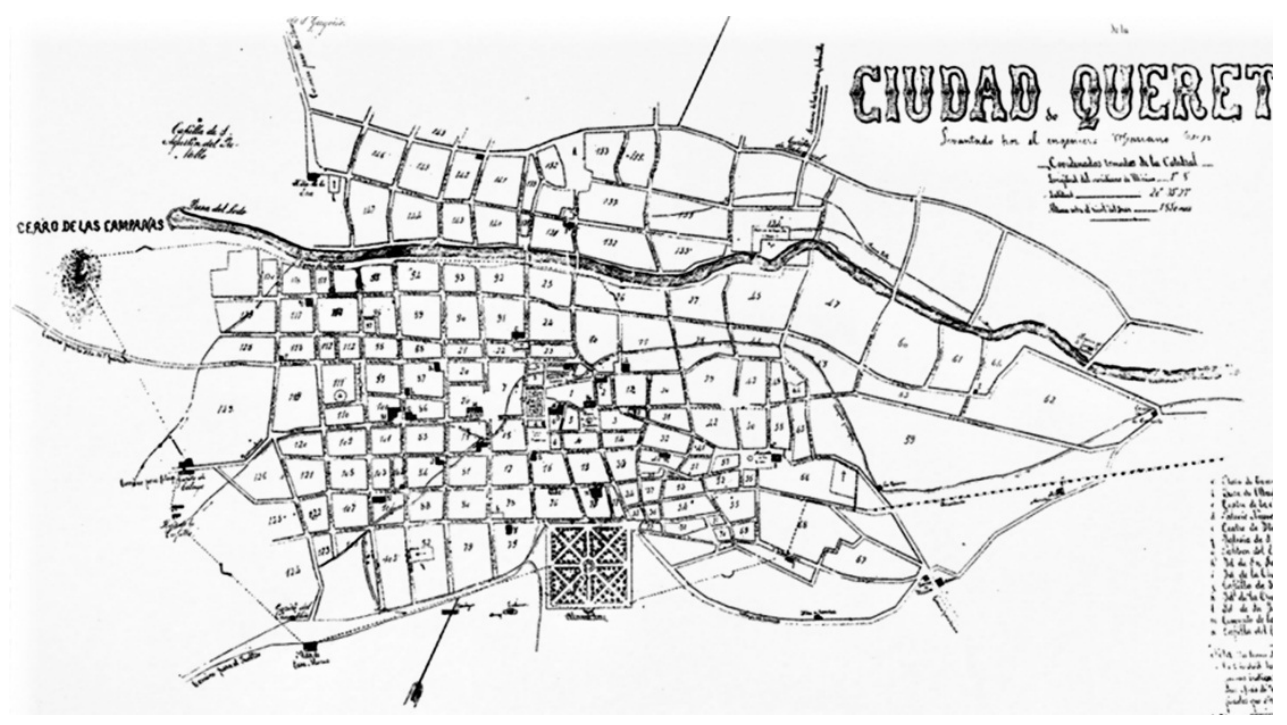

Figure 3. Plot outline of the main roads that strangle the water paths Mexico-Queretaro, railway Guadalajara-México (Pan American Highway embankment) railway. In the ditch, grey blue black road and railway tracks 1897 .

The water pathway has been transformed through the evolution of the urban architecture from 1778 to the present time. The network of streets, acequias (irrigation ditch) and drains has defined the urban scheme of the city, and the urban architecture was instituted during the settlement of Querétaro in 1531 and grew at the same rate as Mexico City. "The water of the River coming from the Cañada village trough of channels network to irrigated a large number of orchards fields that made Querétaro famous for their jolly gardens and great variety of fruits"[13]. At the beginning of the War of Independence, as one may appreciate on Figure 3, the city still kept its original stroke, heart-shaped quasi-symmetric (West) and developed along the Queretaro River. However, the city began to extend towards the Hercules village (Villa Cayetano Rubio), Northeast zone of the Hacienda of Pate and South in limits of the posts along San Miguel de Allende and El Pueblito, result of industrial development. Such growth marked the limits of the city's outline, from an extended conformation. 


\begin{tabular}{ccccc}
\hline $\begin{array}{c}\text { Component water } \\
\text { balance (mm) }\end{array}$ & Mexico & $\begin{array}{c}\text { Queretaro River } \\
\text { basin }\end{array}$ & $\begin{array}{c}\text { Volume } \\
\mathbf{1 0 6} \mathbf{~ 3 3}\end{array}$ & $\begin{array}{c}\text { Percentage } \\
\mathbf{( \% )}\end{array}$ \\
\hline $\begin{array}{c}\text { Average } \\
\text { Precipitation }\end{array}$ & 772 & 557 & 1528 & $\begin{array}{c}100 \text { Mex. } \\
100 \text { Qro. }\end{array}$ \\
\hline \hline $\begin{array}{c}\text { Evaporation } \\
\text { (soil+vegetation) }\end{array}$ & 558 & 464 & 1106 & $\begin{array}{c}72.3 \text { Mex. } \\
83.3 \text { Qro. }\end{array}$ \\
\hline \hline Runoff & 200 & 52 & 397 & $\begin{array}{c}25.9 \text { Mex } \\
9.3 \text { Qro. }\end{array}$ \\
\hline \hline $\begin{array}{c}\text { Groundwater } \\
\text { Recharge }\end{array}$ & 14 & 41 & 27 & 1.8 Mex. \\
\hline
\end{tabular}

Table 1. Comparison of water balance between Mexico and Queretaro River Basin.

\subsection{Regional climate variability}

Jáuregui [14] explains that the behavior of the tropical waves, are more frequent from the East between August and September, which is influenced by the topography across the Volcanic Transversal System, generated the back of the wave, the clouds grow up to 7 or 8 $\mathrm{km}$ producing abundant rainfall. For example, during September 2003, the rains were generated by frontline of (setting in which from the center of a low pressure the isobars deform to move away from him). Aguilar et al. [15] already marked in the 1970s the potential risks of flooding in the Queretaro Valley of Such identified the areas susceptible to flooding and the possible solution of the problem. Future storages with greater feasibility: Atongo, Los Vega, Pueblito, La Cañada, Ixtla, Olvera, Bolaños and Menchaca, could regulate of runoff by $18 \%$ under the time of the study, with a 9 million U.S. Dollars investment of 9 million of dollars. The studies distinguished part of the basin flooding problems: confluence of the Querétaro and Amazcala rivers. In the lower part of the Valley at the confluence of the rivers Querétaro, el Pueblito and the creek of the Arenal occur floods of great magnitude affecting much of the city of Querétaro, area Industrial Benito Juárez, Jurica, also the Obrera, San Pablo, Carrillo Puerto Santa María Magdalena, San Antonio de la Punta, San Juanico, San Pedro Martir and Jurica subdivisions (colonies). Moreover, the "global climate change" should be mentioned, regardless of the relevance today, the impact of the damage by weather disasters, water shortages or water excess address the political country's transformation of the Mexican plateau. The impacts of climate change on the regional components of the hydrological cycle of Queretaro River Basin serves as evidence of the behavior and temperature and precipitation trends, such detailed below, based on the analysis of the historical record of the Querétaro station between 1921 and 2007. Finally it should be mentioned, although the relevance today "global climate change" the impact of the damage by weather disasters, lack or excess water, is close by the social wealth and available technologies to address the political transformations of country and the Mexican Plateau. Analysis of annual precipitation in the urban Queretaro's area with a continuous 86 years record (1921-2007) comprising two periods of observation in one single: 60 years of 
records in central zone (Cerro de Las Campanas) and 30 years in the southern area, current location of the Observatory station (at the foot of the Hill of the Cimatario) was allowed to identify the oscillations of the annual water cycle. It is pertinent to point out however that the urban growth of the Queretaro Valley did not take into account the local effects where the Observatory station is located; therefore, it was considered as a regional influence to assess temporary dynamic precipitation, the annual cycle of the water and the temperature increase. Annual rainfalls were grouped into three bands of occurrence assuming a Gauss distribution, $257 \mathrm{~mm}<\mathrm{P}(95 \%)<857 \mathrm{~mm}, 407 \mathrm{~mm}<\mathrm{P}(68 \%)<707 \mathrm{~mm}, 500 \mathrm{~mm}<\mathrm{P}(5 \%)<$ $600 \mathrm{~mm}$. Figure 3 (low) shows three bands with reference to the average annual precipitation $(557 \mathrm{~mm}$ ) and normalized anomalies. The presence of extreme drought is limited to the year 2000 with $188 \mathrm{~mm}$ and 4 years $(1933,1967,1986,2002)$ considerably wet with $857 \mathrm{~mm}<\mathrm{P}$, the last three with approximately every 20 years. A significant presence of wet years in recent decades with $707 \mathrm{~mm}<\mathrm{P}<857 \mathrm{~mm}$ among the bands of occurrence $95 \%$ - $68 \%$. A greater persistence of dry years with $257 \mathrm{~mm}<\mathrm{P}<407 \mathrm{~mm}$ with occurrence similar to the wet years; $17 \%$, the events show a $5 \%$ occurrence environment than the historical average of $557 \mathrm{~mm}$ minimum and maximum precipitation are affected by a factor of 2 on the historic average, respectively. The rainfall is concentrated between June and August, with $73 \%$ of the total precipitation. In relation to Mexico's seasonal behavior a 4 month period was reported between June and September concentrating 67\% precipitation [16]. Furthermore a pronounced relation to the temporal oscillation was reported in 2001 and 2002, whereas in the same period the concentration was of $79 \%$ and $59 \%$ respectively, allowing to see that there is a seasonal annual water cycle in the Queretaro Valley. It should be pointed out that the analysis was carried out by one single station because the records were not continuous at other stations located within the region, as it may be observed on Figure 4. Table 2 also shows the annual precipitation and evaporation average inside the Queretaro River Basin, as well as daily average temperatures for the 2010.

\section{Climate and climate change}

The weather conditions are typically described in terms of local temperature atmospheric pressure, humidity, wind speed are often described on the basis of the average, a period of 30 years average atmospheric conditions, to scales levels of study. Instead, climate variability refers to variations in the average climate scale condition spatial-time outside the individual weather conditions, i.e. out of context drought, prolonged floods and the effects generated by the El Niño and La Niña Phenomenon. This is why we conceive as climate changes the state average climate and its variability that persists for an extended period. The analysis also relies based on processes at various levels, as it is listed below:

1. Micro-scale Meteorology in agriculture $<100 \mathrm{~m}$

2. Topo-scale or scale local $100 \mathrm{~m}-3 \mathrm{Km}$, pollution and tornadoes

3. Meso-scale 3-100 km., storms, sea breezes of mountain

4. Global-scale $100-3000 \mathrm{Km}$, fronts, cyclones, cluster of clouds 


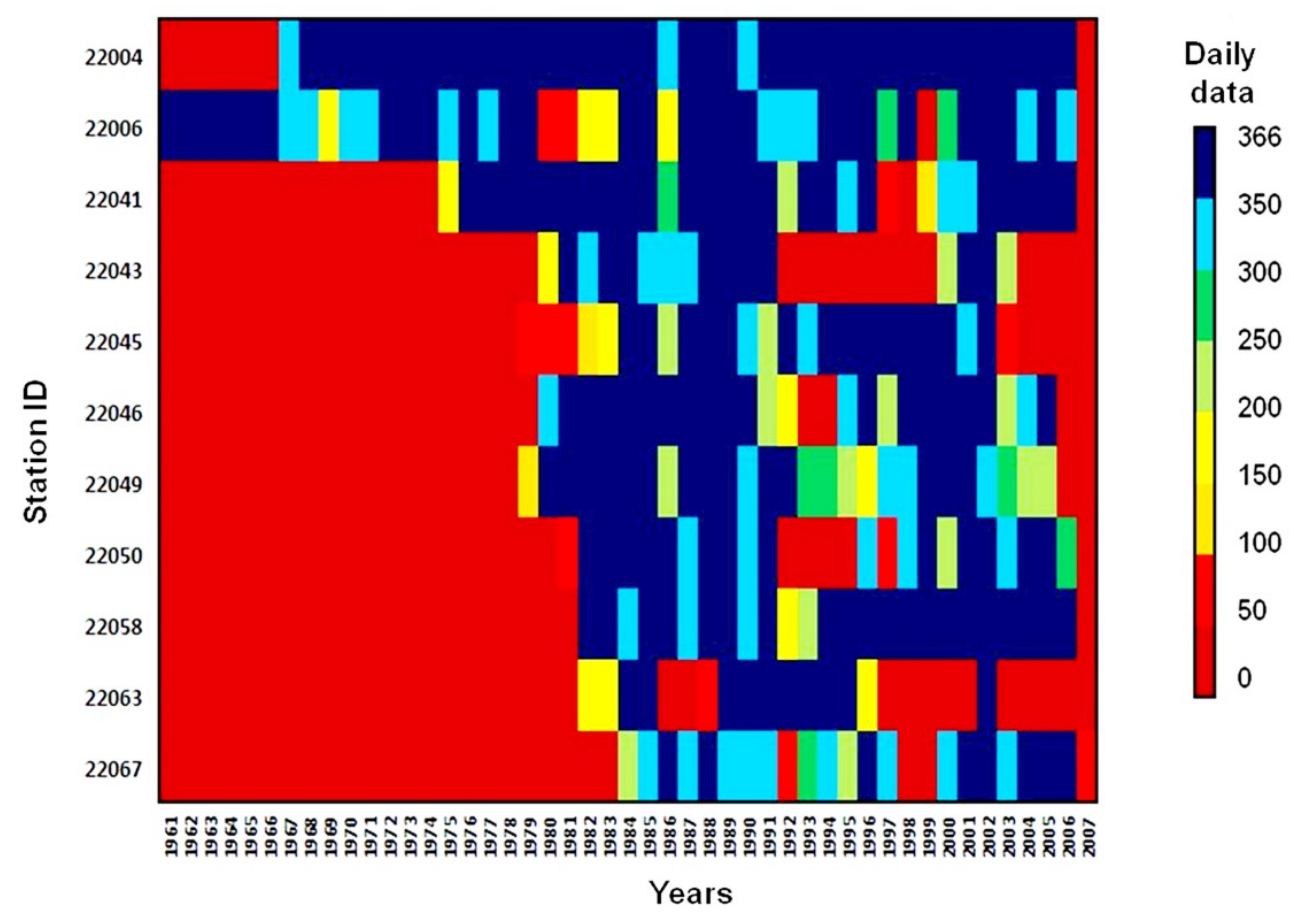

Figure 4. Data matrix of records observed by year and by each one of the weather stations under study.

To establish the vulnerability levels of climate change exposure, susceptibility and capacity for adaptation to the effects of climate change, and differences between climate variability and climate change on a scale space-time scenarios, and its seasonal variation by the effects of temperature increase in the case of the stage critical A2 defined by IPCC. The effects of the spatial variation of natural climate variability on large scale and mesoscale can be observed, and apparently, such are not so evidence that climate variability is greater than the A2 scenario. In the case of the central plateau where Queretaro State and Queretaro City are located, the temperature change in the southern sector is less susceptible than the North; however, the Central region presents a significant variability (Table 2). This could accentuate when compared to mesoscale level and could be magnify to a micro-scale. In order to scale the seasons, apparently the rainy season, summer-autumn, will have little significant change, however it is accentuated during the spring-summer period. In this regard, increased flood risk, by the increase in precipitation is contradictory. It is pertinent to note that this analysis does not provide the rain behavior patterns: duration, intensity and foil. Likewise, the thermal fluctuations at the daily level certainly modify the distribution components of the water balance. The synthesis should identify the relationship of causal effects of climate variability, both at the top-scale levels and micro-scale, in order to specify actions and specific adaptations for each sector and each region. 


\begin{tabular}{|c|c|c|c|c|c|c|c|c|c|}
\hline \multirow{2}{*}{$\begin{array}{l}\text { Climato- } \\
\text { logical } \\
\text { station }\end{array}$} & \multirow{2}{*}{$\begin{array}{l}\text { Altitude } \\
\text { msnm }\end{array}$} & \multicolumn{3}{|c|}{ Temperature $\left({ }^{\circ} \mathrm{C}\right)$} & \multicolumn{3}{|c|}{ Precipitation (mm) } & \multicolumn{2}{|c|}{$\begin{array}{c}\text { Evaporation } \\
(\mathrm{mm})\end{array}$} \\
\hline & & Average & $\begin{array}{c}\text { Máximu } \\
\mathrm{m}\end{array}$ & $\begin{array}{c}\text { Mínimu } \\
\mathrm{m}\end{array}$ & Average & Bias & $\begin{array}{c}\text { Rainny } \\
\text { days }\end{array}$ & Average & Bias \\
\hline $\begin{array}{c}\text { Tres } \\
\text { Lagunas }\end{array}$ & 1610 & $17.8 \pm 8$ & $26 \pm 8$ & $9.7 \pm 9$ & 691 & \pm 172 & 80 & 1446.7 & \pm 105 \\
\hline La Lagunita & 1087 & $20.9 \pm 8$ & $29.1 \pm 12$ & $12.7 \pm 7$ & 711 & \pm 139 & 86.6 & 1452 & \pm 87 \\
\hline Arroyo Seco & 996 & $21.8 \pm 10$ & $29.1 \pm 11$ & $14.6 \pm 9.7$ & 540.6 & \pm 140 & 64.4 & 1430 & \pm 104 \\
\hline Ayutla & 791 & $23.6 \pm 9$ & $30.9 \pm 9$ & $16.2 \pm 10$ & 713 & \pm 176 & 61.8 & - & - \\
\hline Jalpan & 760 & $23.8 \pm 10$ & $31.7 \pm 11$ & $15.9 \pm 9.6$ & 916.5 & \pm 184 & 88.3 & - & - \\
\hline \multicolumn{10}{|c|}{ Central Zone } \\
\hline $\begin{array}{c}\text { C. } \\
\text { Campanas }\end{array}$ & 2568 & $15 \pm 4.7$ & $23.0 \pm 5$ & $7 \pm 3.5$ & 611.4 & \pm 115 & 57.3 & 1782 & \pm 75 \\
\hline Nogales & 2053 & $\begin{array}{r}16.5 \\
\pm 6.4 \\
\end{array}$ & $23.4 \pm 7$ & $9.5 \pm 6.4$ & 362 & \pm 91 & 39.9 & 1714 & \pm 104 \\
\hline Cadereyta & 2044 & $\begin{array}{r}15.9 \\
\pm 6.8 \\
\end{array}$ & $24.2 \pm 7$ & $7.6 \pm 6.3$ & 489 & \pm 88 & 50.4 & 1680 & \pm 91 \\
\hline El Salitre & 1981 & $18.4 \pm 2$ & $28.7 \pm 2.5$ & $8.1 \pm 6.4$ & 270 & \pm 67 & 28.2 & 1451 & \pm 57 \\
\hline $\begin{array}{c}\text { El } \\
\text { Comedero }\end{array}$ & 1749 & $17.4 \pm 8$ & $24.3 \pm 8$ & $10.5 \pm 5.5$ & 432 & \pm 88 & 52.3 & 1886.6 & \pm 70 \\
\hline Toliman & 1720 & $\begin{array}{r}23.6 \\
\pm 8.5 \\
\end{array}$ & $28.5 \pm 9$ & $11.2 \pm 9$ & 377 & \pm 61 & 36.1 & - & - \\
\hline Higerrillas & 1597 & $18.9 \pm 5.4$ & $27.1 \pm 5$ & $10.8 \pm 6$ & 302 & \pm 50.4 & 38.4 & 2170 & \pm 76 \\
\hline Gillen & 1370 & $22.4 \pm 8$ & $31.1 \pm 8$ & $13.7 \pm 9$ & 399 & \pm 139 & 60.3 & 2061 & \pm 122 \\
\hline \multicolumn{10}{|c|}{ South Zone } \\
\hline Amealco & 2629 & $15 \pm 5.7$ & $22.7 \pm 5$ & $7.5 \pm 4.7$ & 820 & \pm 115 & 77.9 & - & - \\
\hline Huimilpan & 2271 & $\begin{array}{r}15.5 \\
\pm 5.7 \\
\end{array}$ & $23.0 \pm 5.4$ & $8.1 \pm 6.4$ & 761 & \pm 188 & 72.2 & 1762 & \pm 98 \\
\hline Santa Teresa & 2092 & $\begin{array}{c}17.1 \\
\pm 6.0 \\
\end{array}$ & $24.60 \pm 7$ & $7 \pm 5$ & 420 & \pm 91 & 35 & 1810 & 115 \\
\hline Juriquilla & 1885 & $17.7 \pm 7$ & $26.0 \pm 6$ & $9.3 \pm 9.5$ & 526 & \pm 100 & 52.4 & 1696 & \pm 103 \\
\hline Carrillo & 1806 & $18.8 \pm 8$ & $27.4 \pm 7$ & $10.3 \pm 7$ & 551 & \pm 105 & 53.5 & 2262 & \pm 120 \\
\hline
\end{tabular}

Table 2. Study data matrix of the observed temperatures, daily, for a one year period, and for each one of the climatologic locations

\section{Analysis of the precipitation}

From the 24 year period (1950-1973) of the "Cerro de las Campanas" station produced a 40 $\%$ coefficient runoff (modified 32.23\%), for an average $619 \mathrm{~mm}$ rainfall, and a coefficient variation of $40.4 \%$. Therefore, the average annual runoff for the entire basin $\left(1486.8 \mathrm{~km}^{2}\right)$ was equivalent to $255 \times 106$ to $110.42 \mathrm{~mm}$ sheet of rain. Yet, on the contrary, the historical precipitation can be reconstructed through the years without the same records that could be associated with the historical reconstruction of the Queretaro City's floods, based upon the 
statistical analysis of historical precipitation series, and its comparison with series of sites in the central region of the Mexican high plateau integrated by the States of Queretaro and Guanajuato. Double mass analysis is considered for the uniformity assessment of the series, taking as reference the Queretaro station [17]. Figure 5 shows a comparison of the precipitation stations Celaya, San Miguel of the State of Guanajuato and the Observatory of the city of Querétaro station. In addition, to observe that Queretaro has an average rainfall in comparison to the other two sites, similar and well defined precipitation persistence at stations of Celaya and Queretaro, may point out terms of the oscillations that can be inferred in the rainfall registered in Celaya, despite of being a period shorter.

The simple rainfall analysis curve mass from the three sites located in Mexico's central region support the zoning hypothesis precipitation of the Mexican high plateau, and the persistence and seasonal behavior of such, as Giddings et al. [18] also noted with the SPI study (Standardized precipitation Index) with 3313 (21 of the Queretaro) stations for the 1940. Such index is widely considered as an indicator to assess the droughts severity or excessive rainfall.

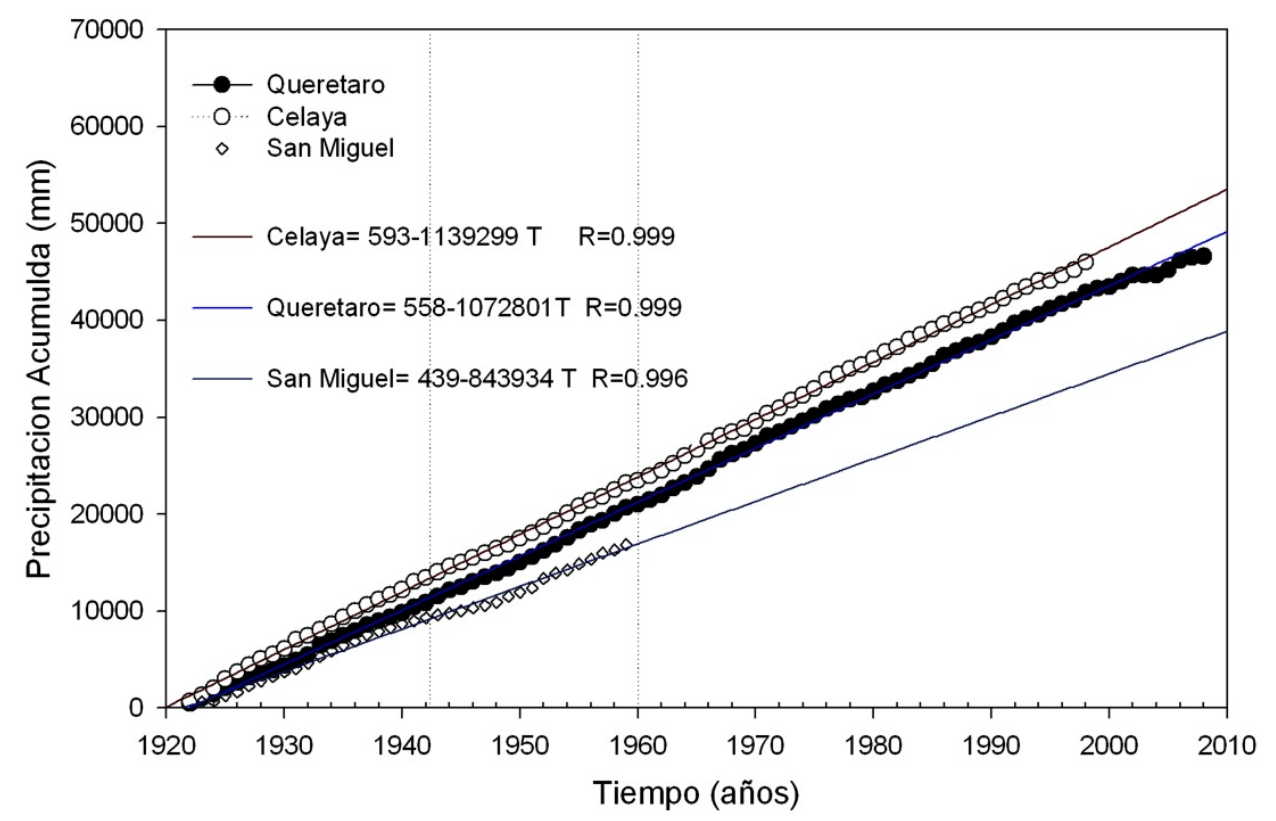

Figure 5. Curve mass of stations of Queretaro, Celaya and San Miguel.

\subsection{Precipitation in Queretaro Valley (QV)}

Reconstruction of the precipitation is based through mainstreaming the fluctuations of the annual water cycle represented by the observation of precipitation it corresponds to a stationary stochastic process by swings in rainfall registered in the last 90 years (1921-2009), the same can be reconstituted under the hypothesis of persistence of the annual cycle governed by this process. 


\subsubsection{The Hurst Exponent}

Wallis and Mandelbrot [19] showed in his auto synthetic work similarity in hydrology, depicting this technical comparison of Markov analysis, in the best way processes hydrological as droughts and floods through. The Hurst Exponent [20]: If the process has a variance and a finite memory, a good process measure can be established:

$$
R(n) / \sigma \propto n^{H}
$$

where $\mathrm{R}(\mathrm{n})$ the range of the sample of size $\mathrm{n}$ and the standard deviation of the sample if the process is independent, produces (whitenoise) Gaussian not correlated, by analogy with the conduct of the spectrum of white light, its random behavior (Brownian noise) produces $\mathrm{H}=0.5$. However, the hydrological series has a $\mathrm{H}>0.5$, usually. Before the evidence, the Hurst exponent is a tool for characterization of nonlinear systems, and the fact that $\mathrm{H}$ is different from 0.5 envisions an underlying consequence of a non-linear dynamics. A study with the precipitation historical data of the period between 1901 and 1995, in Ghana and Venezuela reported Hurst values of 0.638 and 0.586 exponent, respectively [21]. In the particular case of the historical series of three sites considered within the study, threw values between $0.516<\mathrm{H}<0.982$, values with the range reported by Van de Giesen and Mata [21] and the Mandelbrot and Wallis [22]. Based upon the Gaussian noise, such can be constructed with the moving average of a white noise, which remains the story of events with lasting effects. On the other hand, it was derived from a model of annual base of precipitation with sinusoidal behavior of four parameters, with the moving average of the historical precipitation of the Observatory in Queretaro stations, and the series of stations at Celaya and San Miguel de Allende, Guanajuato. On Figure 5, one can see that the behavior of the various models is led by the time space or lag (s). A stationary stochastic permanence for the three sites is clear, no matter the lag. However, the behavior of the historical model series of San Miguel de Allende is 30 years, Queretaro is the dual 60 years between extreme periods of wet and dry, passing through the 1332-1543 Climatic period, Therrel et al. [23]: such study proved the presence of 13 drought events that coincide with the chronological climate rebuilding, with the use of the so-called Dendrology technique. The said study is based on the analysis of the tree's trunk rings in central Mexico, area referred as the States of Puebla, Hidalgo, Tlaxcala, Morelos Federal District and State of Mexico being widely scrutinized between 1450 and 1900 [24]. The historical series of the historic catalogue of natural disasters [25] shows 388 reports about 70 droughts for the central zone without mentioning the State of Queretaro and the city of the same name. The drought analysis reports 3-5 years frequencies, 15, 24 and 55 years, it even mentions a 60 year period associated with solar activity. Between 1970 and 2003, 1744 events were recorded in the country: 232 (13.2\%), 231 $(13.1 \%), 183(10.5 \%), 86(5 \%), 10(0.6 \%)$ in the States of Veracruz, Mexico, Federal District, Chiapas and Queretaro, respectively. Several studies attempted to explain the origin and the rain patterns of Central Mexico ([26], [14], [27], [24]) who analyzed six centuries of historical series (1400-1990) found a drought frequency in the central region of Mexico: 3, 5, 15, 24 and 
50 years, compatible with solar activity, possible to reconstitute the annual rainfall of the last 200 years in order to associate it with floods or droughts. The attention that the persistence in San Miguel de Allende is almost half of Querétaro, 31 and 65.5 years, respectively. While the precipitation extent is of such magnitude, environment to the $50 \mathrm{~mm}$, apparently a local effect causes a greater frequency of catastrophic events in the region North of Guanajuato. However, for the Queretaro Valley region, the greatest amplitude of oscillations indicates the presence of a static stochastic process.

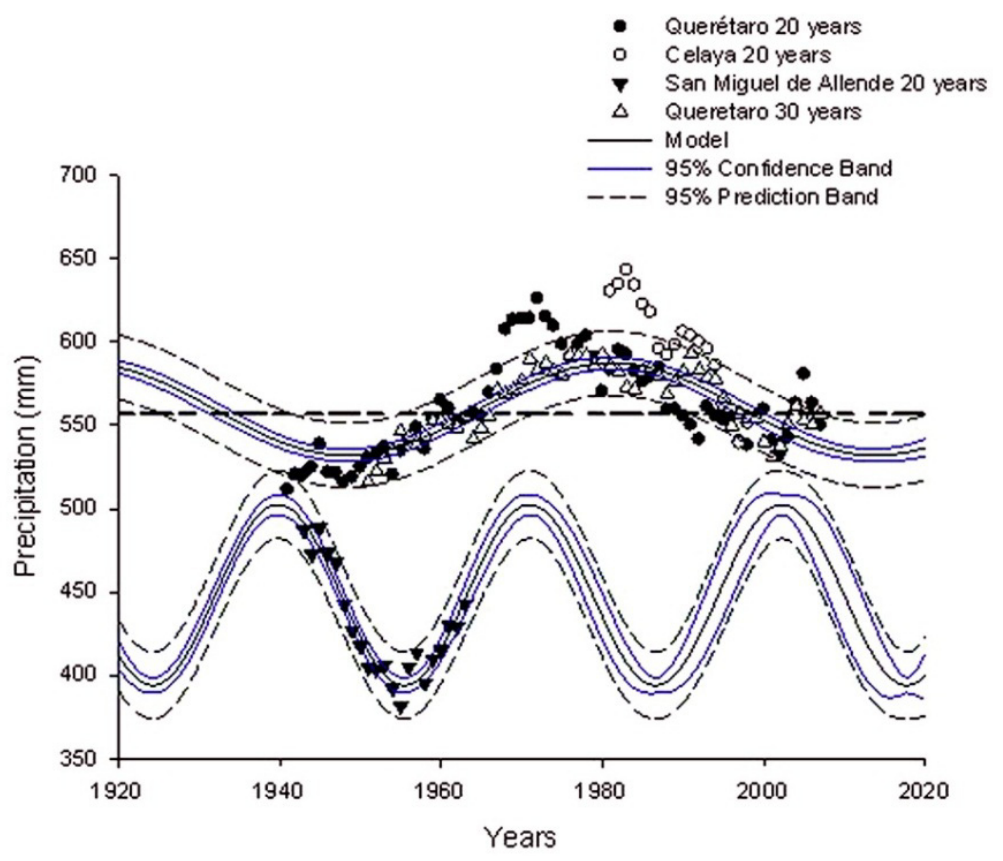

Figure 6. Possible Changes: annual variability or climate changes.

\subsubsection{Possible changes: Annual variability or climate changes}

The rapid urbanization growth directly affects the temperature of the QV and persist the urban growth and deforestation for land use change such condition will cause the average annual temperature further raise and increase the deficit of water supply to the urban and bulk of the QV, without taking into account the changes in the components of the water balance the evaporation increase and heat flow sensitive by the local albedo change. Hunt [28], Hunt and Elliot [29] simulated the climate of a 10000 year period in order to investigate the existence and genesis of mega droughts in the Mexican region suggesting 
that Mexico went through a 19 year mega drought episode in $1550 \mathrm{DC}$, causing diseases and the disappearance of $80 \%$ of the indigenous population. Also Hunt and Elliot [29] identified episodes of major droughts that showed a period of return of 1000 years and a reduction in annual rainfall between $20 \%$ and $40 \%$. The said study detected 13 droughts lasting 10-years, with some wet years, expressing 5 lasting drought events. They conclude that droughts can form independently by the phenomenon of Niño (ENSO) or stochastic processes. The mechanisms associated with El Niño can be identified by the Southeast oscillation pressure abnormal conditions generated by changes in the Walker circulation during El Niño. Both events and stochastic processes produce low surface pressure on the Mexican region, reducing moisture entering the territory and resulting in droughts. In context with the drought episodes previously outlined in Figure 6, shows the historical retrospective of the last 86 years concerning the presence of wet and dry years supported in the drought index, Palmer [30], [31] and normalized anomalies of precipitation [32] 1929, 1960 and 1979 were severely dry years based upon the historical annual average, with rates: 0.53, 0.52 and 0.47, respectively. In contrast 1933, 1967 and 1986, the drought index surpassed the 1.93, 1.83 and 1.75 units corresponding to extremely wet years. It is clear that aspects mixed with global warming generated by urban growth anthropogenic impact on the region's annual water cycle. This situation is necessary to permanently document

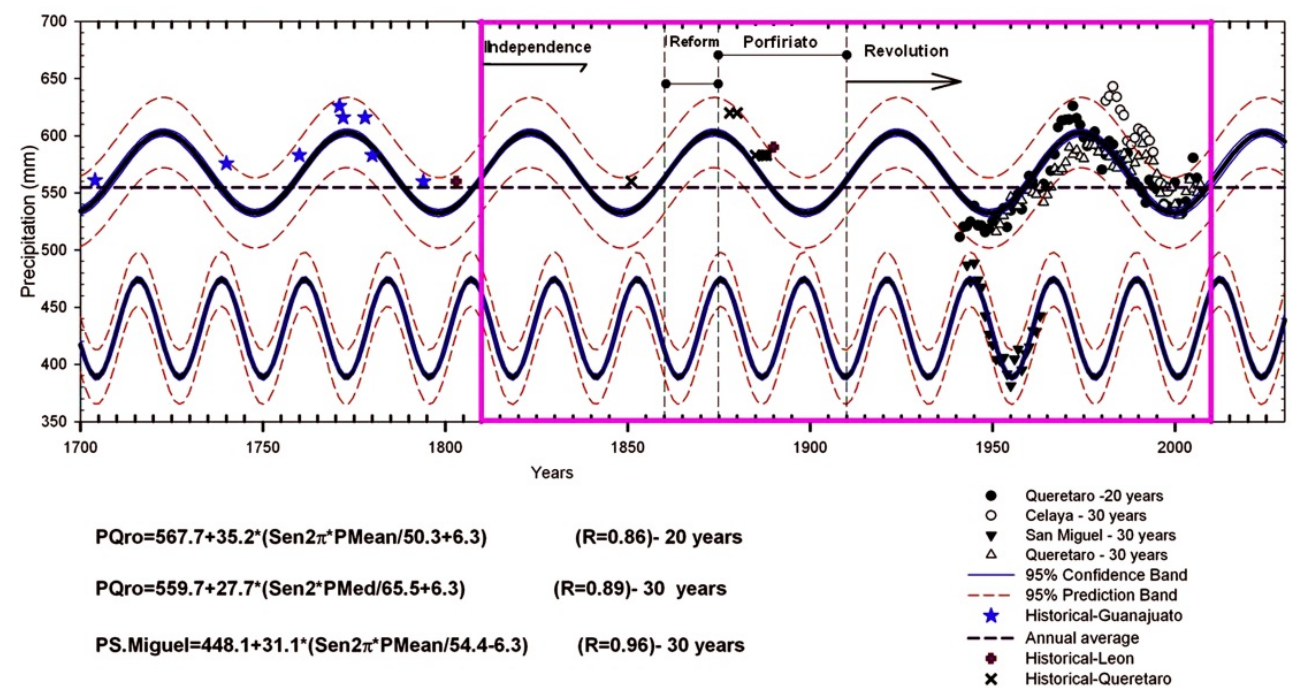

Figure 7. Variability of annual water cycle to 300 years last. Queretaro and San Miguel Station from sinusoidal model. 
climatic variables and components of the hydrological cycle and he fluctuation of the annual water cycle that distinguishes the exchange mechanisms between the biosphere and the atmosphere In addition such conditions develop numerical models adapted to semi-arid environments or ecosystems anthropogenic that assimilate the critical scenarios and establish contingency measures for our own physical environment and water resources management.

\subsubsection{Impacts on water availability}

Within support of the sinusoidal model type shown on Figure 7 and proceeding in reverse form, it was possible to reconstitute the annual rainfall of the last 300 years in order to associate it with floods or droughts. The attention that the persistence in San Miguel de Allende is almost half of Querétaro, 31 and 65.5 years, respectively. While the precipitation extent is of such magnitude, environment to the $50 \mathrm{~mm}$, apparently a local effect causes a greater frequency of catastrophic events in the region North of Guanajuato. However, for the Queretaro Valley region, the greatest amplitude of oscillations indicates the presence of a static stochastic process.

\section{Conclusion}

The Querétaro Valley is a region of large agro-industrial development which has allowed the increase of population density and with it the change in the land use and the availability of water resources. Despite the five aquifers are there in the valley of Querétaro there is a reduction in groundwater levels of $3 \mathrm{~m}$ per year. In the case of the Querétaro aquifer the urban consumption is the major demand of groundwater resources. Furthermore, the Querétaro city due to water infrastructure and topography is susceptible to flooding, mainly in the confluence area of Amazcala and Querétaro rivers, with an average annual rainfall of $557 \mathrm{~mm}$, concentrated in the months of June, July and August (73\%). The historical analyses of the climate variability in the region as well as the documentation of urban growth and water demand are required for decision-making under scenarios of the physical environment of a semi-arid zone as it is the Querétaro Valley region. In this sense, the historical analysis of the Querétaro station displays behavior and tendency of temperature, precipitation, and the occurrence of droughts and floods in the region

The oscillation evidences of the oscillations within the annual water cycle and the temperature and drought periods increase, including severe ones as Hunt (2001, 2001) points out allows us to see, that it is fundamental to generate efficient mechanisms for taking advantage of the rational water resources. At the same time, these characteristics in the pattern demonstrate if there are connections not yet identified between the natural climatic variables and the general alterations due to the global climatic change. In order to identify which are the alterations in the distribution of the hydraulic balance components and the hydrological processes in the river's basin caused by the accelerated dynamic growth within the last 50 years. 
Among the mitigation schemes there is the identification of the driving mitigation zones and the aquifer recharge, taking into account the "Environmental Protection Agency" (EPA, 1993) indications for paved surfaces between 35 and $50 \%$ of the total area where the recharge represents $15 \%$ of the precipitation. In this sense the urban parks could represent an adequate option for the recharge and aquifers recovery of the highly urbanized zones as possible alternate to the contamination and subsidence problems. The great question is to know what would be the effect of the annual water cycle, above all, investigate the precipitation seasonal-space distribution suffering a radical change due to the global climatic change, for there would be dramatic changes to the physical ambience, transformation of the agricultural system components and the water reservoirs, including the water quality. For such reason, the adaptation of climatic change implies the historical, current and future knowledge of the seasonal-space precipitation distribution in order to identify the effects of possible extreme events, heat waves and droughts or great intense storm precipitations. One of the possible solutions for taking advantage of the current hydraulic resources is the direct rain recovery capitation, as being done by different countries and international non-governmental institutions promoted by policies and new technical-legal schemes for the exploitation of rain water. Even though in the immediate future of Queretaro Valley the Aqueduct II project shall mitigate the Queretaro Valley water problem, it is necessary to create policies in order to support the sustainable development and generate an efficient water resource management. At the same time, the water required to satisfy the deficit and its impact within society's development established the concept of "virtual water" which is economically invisible and politically silent, without really making the climatic changes effects visible.

\section{Author details}

E. González-Sosa* and N.M. Ramos-Salinas

Hydraulics Laboratory, Engineering Faculty,

Universidad Autónoma de Querétaro. Ciudad Universitaria,

Cerro de las Campanas. Querétaro State, México

C.A. Mastachi-Loza and R. Becerril-Piña

Centro Interamericano de Recursos del Agua (CIRA), Engineering Faculty,

Universidad Autónoma del Estado de México. Atlacomulco-Toluca Street, México State, México

\section{Acknowledgement}

This work was conducted with the support of: CONACYT (FondosSectoriales CONAGUACONACYT, 2010-2, NO 148159). Also the student's participation is acknowledged.

\footnotetext{
${ }^{*}$ Corresponding Author
} 


\section{References}

[1] Budyko, M.I. The influence of man on climate. Hydrometeoizdat. Leningrad; 1972.

[2] IPCC. Climate Change: The IPCC Scientific Assessment of Climate Change. Eds. J.T. Houghton, G.S. Jenkins and S.S. Ephrains.Cambridge University Express. Cambridge for WMO/UNEP; 1990

[3] Nemec J. and Shaake J. Sensivity of water resources systems to climate change in climatic imputs. Nordic. Hydrology 1982; 23 257-72.

[4] Stockton C.W. and Bogges, W.R. Geohydrological Change Implications Climate Change on Water Resources Development. US Army Coastal Engineering Research Center, Fort Belvoir, VA; 1979.

[5] Lambin, E., B. Turnerb, H. Geista, S. Agbolac, A. Angelsend, J. Oliver T. Coomesf, R. Dirzo, G. Fischerh, C. Folkei, P.S. George, K. Homewood, J. Imbernon, RikLeemansm, X. Lin, E. Morano, M. Mortimore, P.S. Ramakrishnan, J. Richards, H. Skaness, W. Steffent, G. Stoneu, U. Svedinv, T. Veldkampw, C. Vogelx and J. Xuy. 2001. The causes of land-use and land-cover change: moving beyond the myths. Global Environmental Change 2001; 11 261-269

[6] Pickett, Steward T., Burch Jr, Wiliam R., Dalton, Shawne E., Foresman, Timothy W., Grove J. Morgan., Rowntree Rowan. A conceptual framework for the study of human ecosystem in urban areas. Urban Ecosystems 1997 185-199.

[7] Ducrot, R. Water and land management in the periurban catchment of Sao Paulo: a first conceptual framework. Facilitating Negotiations Over land and Water Conflicts in Latin-American Peri-Urban Upsteram Catchment: Combining-Agent-Based Modeling with Role Playing Game Project Negowat. CIRAD-TERA 2005.

[8] Paul, M. and Meyer J. Streams in the Urban Land Scape. Annu. Rev. EcolSyste 2001; 32 333-365.

[9] Fitzharris, B. Land-use change and water balance an example of an evapotranspiration simulation model. Journal of Hydrology (N,Z.) 1974; 13(2) 98-114.

[10] Walton, B., Nawarathna, B., George, B., Malano M. 2009. Future water supply and demand assessment in peri-urban catchments using dynamics approach. 18th World IMACS/MODSIM Congress, Cairns, Australia 13-17 July. 3872-3878.

[11] Steffen, W., Saanderson, A., Tyson, P.D., Jager, J., Matson, P.A., More III B., Richardson K., Shellnhuber, H.J., Turner II, B.L., Wasson, R. J. Reverberations of change: The Reponses of the Earth System to Human Activities. Global Change and the Earth System. Springer-Verlang. Berlin 2005.

[12] Cordera, R., Tello C. La desigualdad en México. Siglo XXI. México 1984.

[13] Septién M., Septién. La historía de Querétaro: desde los tiempos prehistóricos hasta nuestros días. Gobierno del Estado de Querétaro 1999.

[14] Jáuregui, E. Las ondas del este y los ciclones tropicales en México, Ingeniería Hidráulica en México 1967; 21(3) 197-208. 
[15] Aguilar U. G., Venegas M. J. G., Ramírez T. R. Estudios técnicos sobre cimentaciones e inundaciones en el Valle de Querétaro. Tesis para obtener el titulo de Ingeniero Civil. Escuela de Ingeniería. Universidad Autónoma de Querétaro. México; 1974.

[16] Comisión Nacional del Agua (CONAGUA). Estadísticas del agua en México. http://www.conagua.gob.mx/CONAGUA07/Publicaciones/Publicaciones/EAM_2008.pd f (accessed 20 April 2012)

[17] Kohler, M.A. Double-mass analysis for testing the consistency of records and for making adjustments. Bulletin of the American Meteorological Society 1949; 30 188189.

[18] Giddings, L., Soto, M. Rutherford, B. M. Maarouf, A. Standardized Precipitation Index for México. Atmósfera 2005; 33-56.

[19] Wallis, J.R., Mandelbrot, B. B. Self-similar synthetic hydrology. The use of analog and digital computers in hydrology: proceedings of the Tucson Symposium, UNESCO; 1969.

[20] Hurst, H.E. Long term storage capacity of reservoirs. Trans. Am. Soc. Civ. Eng. 1951; $116770-779$

[21] van de Giesen N., Mata J. L. Comparison of the Hurst exponents of historical and GCM rainfall time series. Hydrology days; 2002.

[22] Mandelbrot, B.B Wallis J. R. Some long-run properties of geophysical records. Water Resour. Res. 1969; 5 321-340.

[23] Therrel M. D., Stahle D. W., Acuña S. R. Aztec Drought and the "Curse of One Rabit".American Meteorology Society 2004; 1263-1274.

[24] Mendoza B., Jáuregui E., Velasco V., García-Acosta V. Possible solar signals in historical droughts in central and southeastern México. 29th International Cosmic Ray Conference Pune 2005; 2 369-372.

[25] García Acosta V. La perspectiva histórica en la antropología del riesgo y del desastre. Acercamientos metodológicos. El Colegio de Michoacán. México. Relaciones 2004; 97

[26] Wallen C. C. Some characteristics of precipitation in México. Geografiska Annales 1995; 37 51-85.

[27] García E. Nuevas técnicas de análisis en la climatología. 1997. Memorias del VII Congreso Nacional de Meteorología. Universidad de Chapingo, Estado de México, pp. 39-73.

[28] Hunt B. G. A description of persistent climatic anomalies in a 1000-year climatic model simulation. Climate Dyn. 2001; 17 717-733

[29] Hunt B. G. Elliott T. I. Mexican megadrought. Climate Dyn 2002; 20 1-12

[30] Palmer W.C. Meteorological drought. Research Paper No. 45.U.S. Weather Bureau. (NOAA Library and Information Services Division, Washington, D.C. 20852) 1965.

[31] Willeke G., Hosking J. R. Wallis J. R., Guttman N. B. The national drought atlas. Institute for water resources report 94-NDS-4, U.S. Army Corps of Engineers 1994. 
[32] Ogallo L. J. The spatial and temporal patterns of East African rainfall derived from principal component analysis. Int. J. Climatol. 1989; 9 145-167. 